\title{
Comparative Analysis of Adopted Rural Development Measures in Saskatchewan: Five Case Studies
}

\author{
Suren Kulshreshtha \\ Department of Agricultural and Resource Economics, University of Saskatchewan, Canada
}

Received October 28, 2019; Revised January 2, 2020; Accepted May 13, 2020

Copyright $@ 2020$ by authors, all rights reserved. Authors agree that this article remains permanently open access under the terms of the Creative Commons Attribution License 4.0 International License

\begin{abstract}
Over the last half century, most small regions and communities in Saskatchewan, Canada, have been facing a decline in their population. Major reasons for such a decline is outmigration of residents to larger centers that provide better quality of life as well as lack of new businesses moving into these communities, perhaps due to somewhat unattractive business climate. To secure economic development, some rural communities (including Rural Municipalities - RM) have attempted to lure business and residents through various types of incentives, including the use of tax and nontax incentives. Examples of such incentives have included, but not limited to, property tax incentives -- municipal tax abatement, property tax incentives, and commercial and industrial tax incentives. This study was based on a case study of five Saskatchewan rural municipalities (RM) in Saskatchewan to inquire about the effectiveness of such tax and nontax incentives. These communities were surveyed using a well-structured questionnaire. In most cases, interviewee was the economic development officer of the R.M., or failing that its mayor. Results of the success of the measures were mixed, as only one community indicated some success in attracting new consumer (tourists oriented) services / businesses. Even here, since this RM is located on a major national highway, marginal contribution of these incentives cannot be ascertained fully. Another R.M. indicated that the community was too small to have an economic development programs and joined neighbouring R.M. for joint collaboration. For other three RMs, the success of these incentives was noted to be nil to limited, although in one case, it was argued that the lead period between the implementation of the incentives and current reporting period was too short. This study confirms much of the evidence found in the literature that such impacts typically do not result in attracting new businesses or new residents. Other factors, particularly those related to attractiveness of the community (region) might play a more important role in rural economic development.
\end{abstract}

Keywords Tax and Nontax Incentives, Rural Municipalities, Saskatchewan, Rural Economic Development, Local Governments

\section{Introduction}

Over the last half century, rural population in Saskatchewan has been declining. The province started with a population of 257.8 thousands in 1906, which grew to 1.1 million by 2016 (Government of Saskatchewan, 2019) - an increase of little over four-folds. In 1906, the province was mostly a rural entity, as its rural population constituted $81 \%$ of the total population. Overtime however, like other parts of Canada, it experienced rapid urbanization. For example, between 1906 and 1941, rural population increased, in terms of both level and proportion to total, reaching an equal rural-urban share in 1961, but since then has been decreasing (Figure 1). Saskatchewan during moat recent decade, at the same time, has shown very slow growth, much of which has been through interprovincial migration and to a very limited extent, through international migration.

Migration of people from rural areas to urban centers and to other parts of Canada continues, leading to decline in rural population. At the same time, international migration has no or very little impact on these regions. There is also evidence of significant intra-provincial migration of people from smaller communities to larger ones. Population of the larger communities has increased over the last decade (Table 1). Using the hierarchical order terminology, communities that are not primary wholesale-retail and secondary wholesale-retail have lost their population as well as their 1961 hierarchal status during 1961-2001 period (Stabler and Olfert, 2002). 


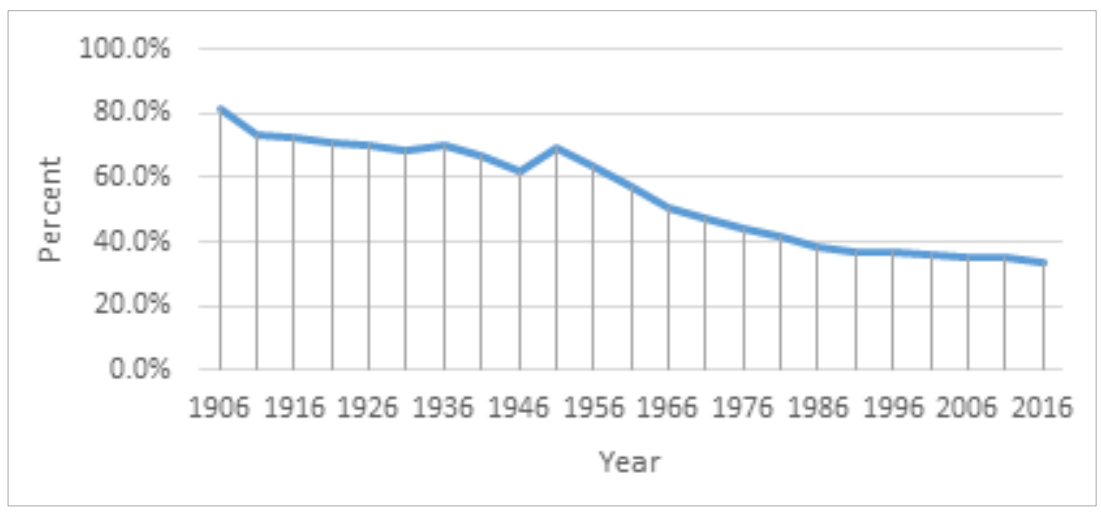

Figure 1. Saskatchewan Rural Population as Proportion of Total Population of Saskatchewan, 1906-2016

Table 1. Change in the Rural and Urban Community Populations, 2011-2016

\begin{tabular}{|c|c|c|c|c|}
\hline \multirow{2}{*}{ Type of Community } & \multicolumn{3}{|c|}{ Population in 1,000 during } & \multirow{2}{*}{$\begin{array}{c}\text { \% change in 2016 over } \\
\mathbf{2 0 1 1}\end{array}$} \\
\cline { 2 - 4 } & $\mathbf{2 0 1 1}$ & $\mathbf{2 0 1 6}$ & Change & $9.9 \%$ \\
\hline Cities & 596.12 & 655.31 & 59.19 & $2.7 \%$ \\
\hline Towns & 145.78 & 149.72 & 3.94 & $-0.8 \%$ \\
\hline Villages & 42.92 & 42.59 & -0.33 & $13.5 \%$ \\
\hline Resort Villages & 4.16 & 4.72 & 0.56 & $1.1 \%$ \\
\hline Rural Municipalities & 174.60 & 176.54 & 1.94 & $-0.3 \%$ \\
\hline Indian Reserves & 56.22 & 56.05 & -0.17 & $-1.2 \%$ \\
\hline Northern Villages, Hamlets, and & 13.58 & 13.42 & -0.16 & $6.3 \%$ \\
\hline Others & $1,033.38$ & $1,098.35$ & 64.97 & \multicolumn{2}{|c|}{6} \\
\hline
\end{tabular}

Source: Compiled from data provide by Saskatchewan Bureau of Statistics, Undated.

Table 2. Growth in Rural Municipality Population, by Size, 2011 to 2016

\begin{tabular}{|c|c|c|c|c|}
\hline \multirow{2}{*}{$\begin{array}{c}\text { Population of RM in } \\
2011\end{array}$} & \multicolumn{3}{|c|}{ Population in 2016 } \\
\cline { 2 - 5 } & $\begin{array}{c}\text { No. of RMs with Increasing Population } \\
\text { or No Change }\end{array}$ & $\begin{array}{c}\text { No. of RMs with Decreasing } \\
\text { Population }\end{array}$ & $\begin{array}{c}\text { Total } \\
\text { RMs }\end{array}$ & $\begin{array}{c}\text { \% RMs with Increasing } \\
\text { Population }\end{array}$ \\
\hline$<500$ & 80 & 121 & 201 & $39.8 \%$ \\
\hline $501-1000$ & 23 & 40 & 63 & $36.5 \%$ \\
\hline $1001-1500$ & 14 & 5 & 19 & $73.7 \%$ \\
\hline$>1501$ & 10 & 3 & 13 & $76.9 \%$ \\
\hline Total RMs & 127 & 169 & 296 & $42.9 \%$ \\
\hline
\end{tabular}

Source: Estimated using data provided by Saskatchewan Bureau of Statistics, Undated.

Rural areas in the province typically house villages, hamlets, smaller towns, and rural municipalities, in addition to First Nation's reservations. The entire agricultural zone of Saskatchewan is administered through rural municipalities (RMs). In 2016, there were 296 RMs. Although their total population in 2016, relative to 2011, has increased from 174.6 thousand to 176.54 thousand (an increase of $1.1 \%$ as shown in Table 1 ), not all RMs have experienced this growth in population. In fact, it appears that the size of the initial population seems to be related to their respective change in population. For the smaller RMs (those below 500 people in 2011), chance of a population growth during 2011-16 period is only 38\%, as against approximately $77 \%$, if the initial population is 1500 or more people (Table 2).

Various reasons have been advanced for the declining rural population. For example, Moazzami (2015) attributed the decline of rural Saskatchewan communities to outmigration, particularly members of younger generation, from rural to urban areas in search of employment, education and other economic opportunities and services provided by urban areas. In Saskatchewan, the economy is highly dependent on exports, which are heavily based on natural resources, including potash, oil, gas, and uranium. In addition, centralization of private and public sector economic activity has fueled urbanization, which has left many rural communities in Saskatchewan without populations above the threshold level necessary to support 
many types of economic activity (Hall and Olfert, 2015). Although Canada has opened doors for international migrants, very few of them have made their residency in rural areas of Saskatchewan. One exception to this is that rural communities located near urban areas (a concept called MIZ - Metropolitan Influenced Zone) that have gained in population because of their proximity to a larger urban center. This may support the conclusion by Mahroum et al. (2007) that often economic development policy has focused on cities as the engines for competitiveness and growth, which tended to overlook or even neglect the capacity and capabilities of rural areas. Saskatchewan situation is not unique, as Porter et al. (2016) have suggested that economic performance of rural regions in the USA, and across the globe, is stagnant despite efforts by governments and local leaders to solve the problem.

The declining trends in rural population have been a matter of concern to not only the residents and local public bodies therein, but also to the provincial and federal policy makers. With the declining rural population in Saskatchewan, public agencies (e.g., rural municipalities and provincial and federal governments) have continuously searched for ways to reverse it. Economic and fiscal instruments that are effective in stimulating private investment and job creation to retain residents in their communities have been noted both in the literature as well as in practice. The regions (and communities) face an added pressure to find ways to grow and sustain their local economies, especially in smaller and remote communities, through a range of factors, such as the decline and restructuring of industries, changes in transportation and communication infrastructure, and regionalization of services (Bruce et al., 2005).

Economic development incentives include a wide variety of tools ranging from planning, the permitting process, and all the way to direct and indirect funding. Business incentives can vary in form, namely tax or nontax incentives depending on the desired investment with its associated economic growth and development end goal. For example, at the local level, municipalities can partner with business for the exchange of investment and job creation (LaSalle, 2014). In addition, government can support businesses by offering tax credits and abatement rebates, among other incentives, to boost investment while creating a favourable business environment in the municipality (Basile et al., 2011). All these measures lead to a change in the competitive position of a region (community) relative to others.

Use of tax concession, such a tax and nontax incentives have been used in various jurisdictions, including Saskatchewan. SEDA (undated) undertook a survey of various Enterprise regions ${ }^{1}$ in Saskatchewan. The survey

1 An Enterprise Region is a conglomerate of several RMs and neighbouring urban areas. The decision to create the new larger regions was based on information about where people live and work, and takes into consideration natural boundaries such as rivers and road patterns found that various urban and rural local governments have used such tax concessions. RMs in 14 of 16 Enterprise regions has used such practices, primarily in the form of tax rebate or abatement for new construction. In order to develop policies that may foster economic development in rural areas, questions that need to be answered include: Have tax and nontax incentives been an effective tool for rural economic development in the context of Saskatchewan RMs? Does the use of such incentives make Saskatchewan's rural municipalities more competitive? These issues need answers, for not only the local policy makes, but also those at the higher levels of the governments. This study was undertaken to fill this void.

This study was designed to investigate rural municipal level tax and nontax incentives that have been adopted by selected Saskatchewan's RMs in order to increase their economic competitiveness, as well as to induce and attract businesses and residents in their local communities. This study was undertaken to meet the following objectives:

1) Review tax and nontax incentives that have been used by the RMs (similar to other North American jurisdictions/locations, but with more emphasis on those under prairie setting), and appraise their effectiveness for rural economic development; and,

2) Provide recommendations for the use of such incentives at the local level within the broad spectrum of Saskatchewan's rural economic development policy.

The scope of the study is limited to the investigation of Saskatchewan RMs, and even within that on five case studies. Any generalization to other jurisdictions should be done with caution.

\section{Study Methodology}

The study was undertaken using two types of research methods: Literature review of concepts related to rural economic development, and surveys of selected rural municipalities (and other rural communities) in Saskatchewan.

\subsection{Literature Review}

Available literature was reviewed for two topics: One, concept(s) related to factors that lead to economic growth of a rural region through improvement in its competitiveness level. One of the rationale for providing tax and nontax incentives might be to make the region more competitive. Since improved competitiveness may be instrumental to the success of a region to attract new business activity or people, the relevance of factors that affect these processes is needed. One complicating factor is that competitiveness of a smaller region could be affected

(Government of Saskatchewan, 2009). 
by that of the larger regions, which needs to be included in this review as well. Two, a second review was done to develop an understanding of the types of tax and nontax incentives that have been or could be used to foster economic development of a rural region

\subsection{Survey of Saskatchewan's Rural Municipalities and Rural Regions}

Although the conceptual review of the tax and nontax incentives suggested their ineffectiveness in fostering small area or rural development, more evidence that is empirical was required. The objective was to identify rural regions in Saskatchewan that had used tax and nontax incentives for their specific community / region's economic development, and to assess their efficacy based on their specific response. To this effect, two types of surveys were undertaken:

Survey One: A formal survey of five rural municipalities in Saskatchewan; and

Survey Two: An informal survey of several rural communities.

In both of these surveys, focus was to identify the type of tax and nontax incentives used and their effectiveness in the context of rural community economic development.

\subsubsection{Formal Survey of Saskatchewan Rural Municipalities}

A sample of six RMs was selected from a short list of all
RMs in the province. The selection was not based on random sampling procedure, but was close to being a purposive selection process. Various RMs were selected based on their economic and demographic features, along with past population change. They varied from a small size region of only 209 residents in 2011, to a largest RM housing 8,354 people. Some of these RMs showed a population increase, while others were facing a declining population base. In this study, seven RMs were contacted.

The study questionnaire included questions related to basic information about the community and its perception of local economic development, followed by questions related to the incentive plan used by the local government for economic development either through attraction of businesses or residents. The evaluation of the effectiveness of these incentive measures were the subject of these questions, followed by a question related to the challenges faced, and the type of help needed to foster local economic development.

Two of the originally selected RMs, in spite of several attempts refused to provide any response to the questionnaire. Their reasons included: very busy time, lack of staff, and not relevant. The survey was closed in March 2018 using only five RMs as the sample (as shown in Table 3). The entire sample RMs had implemented some type of tax-nontax incentives. Only one of these RM has a growth in population, perhaps due to vicinity of potash mines. The survey results were analyzed using cross-tabulations and descriptive statistical measures.

Table 3. List of Sample Saskatchewan Rural Municipalities

\begin{tabular}{|c|c|c|c|c|c|c|}
\hline Rural Municipality & RM No & $\begin{array}{c}\text { 2001 Census } \\
\text { Popula-tion }\end{array}$ & $\begin{array}{c}\text { 2016 Census } \\
\text { Popula-tion }\end{array}$ & Change (\%) & $\begin{array}{c}\text { Potash/Other } \\
\text { Mines }\end{array}$ & $\begin{array}{c}\text { Used Tax /Nontax } \\
\text { Incentives }\end{array}$ \\
\hline Moose Jaw & 161 & 1,338 & 1,163 & -13.1 & Yes & $\begin{array}{c}\text { Yes (Business and } \\
\text { Residents) }\end{array}$ \\
\hline Prairie Rose & 309 & 345 & 220 & -36.2 & Yes & $\begin{array}{c}\text { Yes (Business and } \\
\text { Residents) }\end{array}$ \\
\hline Orkney & 244 & 1728 & 1875 & 8.5 & No & $\begin{array}{c}\text { Yes (Business and } \\
\text { Residents) }\end{array}$ \\
\hline Mervin & 499 & 1274 & 1256 & -1.4 & No & $\begin{array}{c}\text { Yes (Business and } \\
\text { Residents) }\end{array}$ \\
\hline Langenburg & 181 & 647 & 557 & -13.9 & Yes & $\begin{array}{c}\text { Yes (Personal tax } \\
\text { incentives) }\end{array}$ \\
\hline
\end{tabular}

Source: Statistics Canada (2016a, 2016b, 2016c, 2016d, 2016e), and Wikipedia (2018). 


\subsubsection{Informal Survey}

In addition to the survey of five RMs, an informal survey of some RMs and rural communities in Saskatchewan was also undertaken to evaluate their experience in terms of economic development incentives. A total of $30 \mathrm{RMs}$ and 28 smaller communities were contacted for this survey. Like previously, selection of these RMs and rural communities was not based on a random selection process. Therefore, any generalization for the entire province should be done with caution.

\section{Results and Discussion}

\subsection{Competitive Position of Rural Regions in Saskatchewan}

As noted above, one of the reasons behind use of tax and nontax incentives may be to improve the competitive position of a given region relative to others. Since the competitiveness of smaller regions is a reflection of a larger region, a review of competitive position of Canada and Saskatchewan was reviewed. KPMG (2016), based on a comparison of ten North American and European countries found that Canada has the second business costs, only next to Mexico. Canada's competiveness is comparable to other developed nations with very good institutions and business sophistication (KPMG, 2016). For Saskatchewan, although no formal studies has evaluated its competitiveness of various industries, it has been stated that the competitiveness status of Saskatchewan could be reflected in the cost of doing business in Saskatchewan. This, according to Enterprise Saskatchewan (2012) has been reported to be competitive and comparable to other provinces in Canada. The attractiveness of Saskatchewan is credited to low corporate income and property taxation, competitive labor costs, and a variety of economic opportunities. Saskatchewan has the second-lowest taxes in Canada, (next to Alberta) with the exception of sales and excise tax, and personal income tax. For the rural areas (smaller towns or RMs), no study was found that has evaluated their competitiveness.

\subsection{Types of Economic Incentives Used}

Government entities and institutions are vital in community economic development as their role in local economic development is to encourage investment so that local communities can have an increased capacity to develop their own wealth. In most RMs, the responsibility of economic development planning falls on either the municipal council or the chief executive office. In some cases, an economic development officer is entrusted with this responsibility. All sample RMs (except the RM of Prairie Rose) reported having no defined / allocated budget for economic development activities.

In the process of encouraging private sector investment and growth, incentives can be awarded to specific businesses and industries in exchange for certain business conditions (Reid, 2013). The Council for Community and Economic Research (2013) has explained that incentive programs come in two forms: (1) tax program and 2) nontax programs (Table 4). The tax programs are critical tools or incentives that are administered in the form of tax credit, tax deduction, tax abatements, tax exemptions, tax refund or tax rebate. The nontax programs are direct or indirect financing programs providing capital resources to a company with or without third-party involvement, e.g., grants, loans etc.

Table 4. Types of programs used to enhance rural development

\begin{tabular}{|l|ll|}
\hline \multirow{4}{*}{ Program } & \multicolumn{1}{|c|}{ Forms } \\
\hline \multirow{4}{*}{ Tax program } & $\bullet$ & Tax credits \\
\cline { 2 - 3 } & $\bullet$ & Tax deductions \\
\cline { 2 - 3 } & $\bullet$ & Tax abatements \\
\cline { 2 - 3 } & $\bullet$ & Tax exemptions \\
\cline { 2 - 3 } & $\bullet$ & Tax refunds \\
\hline \multirow{5}{*}{ Nontax program } & $\bullet$ & Tax rebates \\
\hline \multirow{5}{*}{} & $\bullet$ & Grants \\
\cline { 2 - 3 } & $\bullet$ & Loans \\
\cline { 2 - 3 } & $\bullet$ & Loan guarantees \\
\hline \multirow{5}{*}{$\bullet$} & $\bullet$ & Preferential interest rates \\
\cline { 2 - 3 } & $\bullet$ & Bonds \\
\cline { 2 - 3 } & $\bullet$ & Insurance \\
\cline { 2 - 3 } & $\bullet$ & Equity investments \\
\hline
\end{tabular}

Source: Council for Community and Economic Research (2013)

Table 5. Example of a Commercial Tax Incentive

Any existing business will qualify for the following assessment exemptions*:

- The assessment exemption** will be applied to any increased assessed value, GREATER THAN \$500,000 (improvement), of an existing building due to new construction;

- $\quad$ The assessment exemption will be applied to any increased assessed value GREATER THAN \$500,000 (improvement), of an existing building due to renovations that require a building permit.

- The exemption will also be applied to the assessed value GREATER THAN $\$ 500,000$ of any expansion or new construction on bare land.

* The exemption does not apply to the assessment of the land. The exemption will be applied as follows:

- $100 \%$ Construction Year or portion thereof exempt in year one

- $\quad 80 \%$ exempt in year two

- $60 \%$ exempt in year three

- $40 \%$ exempt in year four

- $20 \%$ exempt in year five

- $\quad$ Full taxation in year six

The exemptions are applied once the expansion (additions/improvements) or new construction is assessable.

** Council reserves the right to approve each incentive package individually and to customize incentives to any specific project.

Source: Survey response. 
Various sample RMs in Saskatchewan used two types of incentives for attracting businesses and residents: (1) Property tax incentive, and (2) Commercial and industrial tax incentives. A typical example of commercial tax incentives is presented in Table 5. In most situations, the incentive was for new construction (homes or business) or renovating /refurbishing existing buildings. Similarly, the nature of tax incentive for a typical residential development included: "construction concessions may be granted for new residential construction by way of property tax abatements as follows, upon approval of council: Year of construction $100 \%$ abatement of municipal and school taxes; Year 1 100\% abatement; and Year 2 50\% abatement'. These incentives were available for both the existing as well as new residents or businesses.

\subsection{Effectiveness of Tax-Nontax Incentives}

\subsubsection{Factors Affecting Community Economic Growth}

Evaluation of any policy measure to improve economic development of a rural area need to be compatible with factors that affect its development. Kusmin (1994) compared U. S. counties and found business motivation to be a major factor affecting a region's growth, along with tax and spending variables reflecting that a government can create a business-friendly environment that can contribute to economic growth. Such an environment should result in more business activity and improvement in region's population. Straka and Tuzova (2016) suggested a combination of factors affecting a community economic development, including demographic area, economic area, social, and area of location and facilities of the municipality. Resilience of rural regions may require various types of strategies, including utilizing government assistance to farmers and rural regions to maintain public goods that may otherwise fade away (Ashkenazy et al. 2018).

Effectiveness of any policy measure needs to be examined in light of their effect on the objective of the decision maker. If the objective function of the decision maker is improving economic health of the region, and maintain resiliency, the effectiveness need to be examined in these contexts. Therefore, for any policy measure to be effective, it should affect the probability of encouraging economic development activities. Typical measure of economic development include increase in employment or residents, although often the two go together. The former is created either by new businesses being attracted to the region or through an increase in the scale of business activity of the existing businesses. The increase in the residents could be an aftermath of increase in business activity, although new businesses are also attracted to a region if skilled workers are available. Thus for a business, attractiveness is related to economic motive, although non-economic factors may be present as well.

Similarly, for residents quality of life in the community is an important factor. Many factors may contribute to this attractiveness, including natural amenities, public services, fiscal policy of the local governments, as well as other conditions that affect quality of life. Much of the business activity as well as in-migration of people is related to attractiveness of the community (region).

Evaluation of a policy measure could be done through comparing with and without tax and nontax measures for a given community. An indirect test for the effectiveness of a fiscal measure could be the marginal change in the community's economic development during a period post-implementation.

\section{Results: Response of Study Rural Municipalities}

\subsection{Efficacy of Incentives}

Almost all sample RMs expressed the opinion that property tax incentives were the most effective type of instruments for their region. Three of the five RM (Langenburg, Orkeny and Prairie Rose) indicated that tax incentives were very effective for businesses. For the residents, although the RM of Langenburg did not provide any financial incentives, providing services and amenities were reported to be more successful in attracting residents to the RM.

Each of the five study RMs were asked to provide an evaluation of the incentives used for attracting businesses by noting the degree of success in economic development of the region. Four of the five RMs indicated that their tax incentive program was successful in attracting businesses to the RM, while the RM of Prairie Rose suggested the opposite (Table 6). This RM had very small population base and faced some competition from neighboring RMs. The RM of Langenburg indicated three businesses moved to the RM, but one of them has since closed. Food services-related businesses were among those attracted to the RM, and would likely be attracted in the future. Furthermore, given that this RM is located on a national highway, and attracts many tourists passing through, these changes may not be attributed to the incentives provided by the RM. Thus in spite of the optimism shown at the RM administration level, the success of these incentives can be regarded as minimal. 
Table 6. Success of Tax and Nontax Incentives offered by Study Rural Municipalities, 2017-18

\begin{tabular}{|c|c|c|c|c|}
\hline Langenburg & Mervin & Moose Jaw & Orkney & Prairie Rose \\
\hline \multicolumn{5}{|c|}{ Has any business moved into the community over the last five years? } \\
\hline $\begin{array}{l}\text { Yes }(3 \text { new } \\
\text { businesses); One of } \\
\text { them closed down } \\
\text { since then. }\end{array}$ & $\begin{array}{l}\text { Yes (Mineral } \quad \text { service } \\
\text { development; Tourism related) }\end{array}$ & Yes & Yes & No \\
\hline \multicolumn{5}{|c|}{ What were the contributing factors? } \\
\hline $\begin{array}{l}\text { Needs of community } \\
\text { (Lack of food industry } \\
\text { options) }\end{array}$ & $\begin{array}{l}\text { Mineral resource development; } \\
\text { Improved outlook in } \\
\text { agriculture; Tourism related. }\end{array}$ & $\begin{array}{l}\text { Customer service; } \\
\text { Business friendly policy; } \\
\text { Transportation } \\
\text { accessibility. }\end{array}$ & $\begin{array}{l}\text { Location; Taxes; Trading } \\
\text { area of people }\end{array}$ & $\begin{array}{l}\text { Too small a } \\
\text { community }\end{array}$ \\
\hline \multicolumn{5}{|c|}{ Do you expect any new businesses in the next five years? } \\
\hline $\begin{array}{l}\text { Food service related } \\
\text { businesses }\end{array}$ & Yes & Yes & Yes & No \\
\hline \multicolumn{5}{|c|}{ What would be the contributing factors? } \\
\hline Consumer preference & $\begin{array}{l}\text { Resulting from Mineral } \\
\text { resources spin-offs; Businesses } \\
\text { meting local demand for goods } \\
\text { and services }\end{array}$ & $\begin{array}{l}\text { Resulting from support for } \\
\text { the City RM industrial } \\
\text { park initiative }\end{array}$ & $\begin{array}{l}\text { Resulting from taxes, } \\
\text { infrastructure - no main } \\
\text { highways, trading area }\end{array}$ & $\begin{array}{l}\text { Community too } \\
\text { small and too } \\
\text { remote }\end{array}$ \\
\hline
\end{tabular}

Table 7. Barriers/Challenges to Economic Development Faced by Communities, 2017-18

\begin{tabular}{|c|c|c|c|c|}
\hline Langenburg & Mervin & Moose Jaw & Orkney & Prairie Rose \\
\hline \multicolumn{5}{|c|}{ What factors serve as a barrier to community economic development? } \\
\hline $\begin{array}{l}\text { Too close to drive to larger city } \\
\text { centers } \\
\text { Limited options for internet } \\
\text { communication technology } \\
\text { Poor quality internet technology } \\
\text { High housing } \\
\text { prices }\end{array}$ & $\begin{array}{l}\text { High cost of maintenance of } \\
\text { road infrastructure created by } \\
\text { loss of rail line increased } \\
\text { transportation costs; } \\
\text { Inability of the town to develop } \\
\text { new lots for housing; }\end{array}$ & $\begin{array}{l}\text { Lack of transportation } \\
\text { upgrades } \\
\text { Lack of water } \\
\text { resources } \\
\text { Lack of space for } \\
\text { housing }\end{array}$ & Infrastructure & N.R. \\
\hline \multicolumn{5}{|l|}{ Main challenges faced } \\
\hline $\begin{array}{l}\text { Too close to the city - bypassing } \\
\text { the community }\end{array}$ & Competitiveness in business & Serviced land & $\begin{array}{l}\text { Funding for } \\
\text { infrastructure } \\
\text { development }\end{array}$ & N.R. \\
\hline
\end{tabular}

\subsection{Constraints to Economic Development}

All five RMs reported facing some constraints in fostering their respective economic development. Quality of transportation and cyber technology were cited as the most common factors (Table 7). The RM of Langenburg indicated that due to being located on a major highway, it makes its own economic development somewhat difficult, as people bypass the community to shop in the larger communities located nearby. High prices for homes and limited options for internet technology were also noted as other barriers to a community's economic development.

In the RM of Mervin, the high cost of road maintenance and infrastructure caused by rail line abandonment is a major barrier to development. Other challenges faced by the RM include high competitiveness from other regions. The RM of Moose Jaw is also facing a lack of transportation upgrades as a barrier, along with a lack of water resources and space for housing. The latter is perhaps a sign of rapid development in the RM. For the RM of Orkney, infrastructure and lack of funds for its improvement were reported to be the major barrier to local development. The RM of Prairie Rose did not report on this question, partly because development is limited due to its location and current size. All of these are contributors to the competiveness (or lack of it) of the RMs.

\subsection{Suggested Solutions to Fostering Economic Development}

The RMs were also asked, in addition to the barriers of their economic development, their preferred solutions. Four of the five RMs (Langenburg, Mervin, Moose Jaw and Orkney) noted funding of activities in the RM by higher level of the governments is important. Assistance to keep taxes (at the RM level) lower, and more consultation with the RM for location of the industry, was noted by the RM of Orkney.

\subsection{Results of the Informal Survey}

The informal survey was carried out in 30 RMs in the province. Results indicated that 18 (60\% of total surveyed) had implemented some type of tax-nontax incentives 
(Table 8). Tax rebate and abatement for new construction was the most commonly used measure. Business incentive policy, as well as residential incentive policy, were also noted as being used, but no details on the nature of this policy were available. No information was available on the effectiveness of these measures.

Table 8. Types of Measures for Economic Development by Saskatchewan RMs (Based on an Informal Survey)

\begin{tabular}{|c|c|c|}
\hline Type of Measure & $\begin{array}{c}\text { No. of Rural } \\
\text { Municipalities }\end{array}$ & $\begin{array}{c}\text { Percent of } \\
\text { Total } \\
\text { Responses }\end{array}$ \\
\hline Property Tax Incentive & 9 & 45 \\
\hline Business Incentive Policy & 3 & 15 \\
\hline $\begin{array}{c}\text { Multi-Unit Residential Policy } \\
\text { Residential Incentive Policy }\end{array}$ & 3 & 15 \\
\hline Capacity Building of Businesses & 1 & 5 \\
\hline $\begin{array}{c}\text { Tax Abatement for Major } \\
\text { Developers }\end{array}$ & 1 & 5 \\
\hline $\begin{array}{c}\text { Business Loans Program } \\
\text { (Including Collateral) }\end{array}$ & 1 & 5 \\
\hline Tax Concession Policy & 2 & 10 \\
\hline Total Responses & $20 *$ & 100 \\
\hline
\end{tabular}

* Number of responses exceeds the number of RMs due to multiple responses by some RMs.

Source: Informal Survey

In addition to the study RMs, another survey was undertaken involving 28 rural (non-urban) communities. Half of these communities had implemented some type of incentive program. Only five of the 14 communities that had implemented the incentives had some success in attracting businesses or residents, including existing business restoration. Thus, only $18 \%$ of these communities had reported any success with these incentives. The nature of this success requires further research activity.

\subsection{Observations based on Literature Review}

A review of economic development of rural regions suggested that different types of polices could make a difference on rural development. Ofoshuhene (1999) reported that in the past federal (Canadian) governments have initiated and implemented top-down development policies and programs. However, over the few years, there has been a shift from the rigid, hierarchical, top-down approach to a more flexible, decentralized, bottom-up grassroots approach. This perhaps may suggest a stronger role for the local governments in decisions related to their economic development. Policies also have a spillover effect on other regions and other industries (Bollman and Ferguson, 2019). Their results suggest that policies not only affect farmers themselves but also, although indirectly, affects growth in the surrounding communities. They examined the case of removal of agricultural subsidies. Study by the Rural Development Institute (2015) has reported all Manitoba municipalities have invested in financial and human capital in trying to grow and improve their community -- where they chose to invest their human and financial capital is what makes the difference.

On the subject of effectiveness of tax and nontax incentives, the literature review suggests a rather smaller role of tax incentives in fostering rural economic development. Some studies suggest that when businesses choose between two or more sites/communities, they weigh several factors on the business climate that is important to their industry (Deller et al., 2001; Shaffer et al., 2004). Incentives are often part of this equation, but rarely play a decisive role until the last few sites are being compared. Competing communities may choose to bargain with the business and even to out-bid one another (International Economic Development Council, undated). This practice may be viewed as unfavorable, as it may create a negative environment between competing municipalities. Rainey and McNamara (2002) indicate that although taxes can have an impact on the location of industrial activity, it is only one of several factors that firms examine when making their location choices. Recent research shows that much of the growth in rural areas is occurring in areas that are adjacent to urban areas, suggesting that location of the community is a major factor affecting its economic development. For these communities, tax policy can be a determinant in whether a potential firm chooses a community on one side of the metropolitan area as opposed to a community on the other side. However, tax policy alone may not be a good incentive for a business to move in that region; emphasis of the community / rural municipality should be to enhance availability of those factors that are crucial for attracting a new business.

\section{Summary}

This study was undertaken to review tax and nontax incentives that have been used in selected rural jurisdictions/locations in Saskatchewan. It was based on a case study of five rural municipalities (RM): Langenburg (No. 181); Mervin (No. 499); Moose Jaw (No. 161); Orkney (No. 244) and Prairie Rose (No. 309). These RMs varied from small (with a population of 220 people in 2016 for the RM of Prairie Rose) to large RM (with a population of 1256 people in 2016 for the RM of Mervin). The survey was undertaken using a questionnaire sent electronically to the RM Administrators. Four of these RMs has implemented business and residential property tax incentives. The sample RMs provided their experience in undertaking economic development.

In all other RMs, the responsibility of economic development planning falls on the municipal council or the chief executive office. All RMs (except the RM of Prairie Rose) has no defined / allocated budget for economic development activities. Some of these RMs do not have adequate resources to employ an economic development officer. 
The effectiveness of these policies was reported to be somewhat mixed - two of the five RMs (Mervin and Moose Jaw) indicated success, while the other three RMs did not respond to this question, although these three RMs (Langenburg, Orkney and Prairie Rose) reported tax incentives to be a successful strategy for businesses. For residents, the local condition and amenities were the reasons for attracting new residents to the RM. Of these, four RMs had suggested that the incentive programs were successful, although the nature of this success was only documented by the RM of Langenburg as attraction of three new businesses. Even here, what role was played by the incentives could not be determined. The success of these incentives for this RM was not reflected in its population growth. A growth in population was noted only for the RM of Orkeny, which has housed mining operations. For the other three RMs (Langenburg, Mervin, and Moose Jaw) the population either stabilized or did not decrease. The experience of the RM of Prairie Rose matched with its experience of lack of success in such a program. The informal survey of Saskatchewan RMs and rural communities reported much lower effectiveness of these measures. In this survey, an even smaller portion of the RMs, and non-urban communities had a successful economic development after implementing an incentive program.

There is mixed evidence in the literature on the role played by tax and nontax incentives for rural economic development. Some studies have suggested that they can be valuable tools that can influence the decision being made by individuals and businesses. Other studies suggest that economic growth of rural municipalities is dependent on consistent and effective policies that enhance a high level of competitiveness. Results of this study confirm similar experience for the Saskatchewan RMs.

With respect to competitiveness of a region, tax-nontax incentives may have an effect on it but as Deller et al. (2001) suggests that amenities, quality of life, and local economies performance have predictable relationships with competitiveness. Local and provincial governments, therefore, may put more emphasis on development of such rural amenities for attracting residents and businesses.

In summary, based on the evidence presented, the tax and nontax incentives have not brought significant improvements in the economic development of the selected Saskatchewan RMs. Based on their lack of effectiveness, one may argue that they are poor policy instruments for rural economic development. Two reasons for this type of conclusion are: (1) their effect can be offset by other jurisdictions with similar effort; and (2) what businesses seek most is access to resources and skilled workers, in addition to infrastructure and business opportunities. However, these incentives can make a difference in the business location decisions when the choice is narrowed down to two or more sites with a similar economic jurisdiction.

\section{Implications for Rural Economic Development Policy}

Challenges faced by the study RMs included poor internet technology, high cost of road maintenance of infrastructure, lack of water resources, and lack of space for housing. Many of these are a result of lack of resources. Based on the survey results for the nature of policy needed for rural economic development, more funding opportunities for lower level governments was noted most frequently suggestion made by the study RM officials. This suggestion was made by all five RMs, in light of the fact that their sources of revenue have decreased. However, ensuring accountability in public spending is equally important. Savoie (2000) suggests providing financial assistance through agreements within a designated period on a sliding scale may be an effective method of helping rural area economic development. Development of institutions, such as an Area Development Council, transfer of funds from higher-level governments to keep the local taxes low, and more consultation with the RMs for industry location were also noted.

In addition, the provincial level government could also help a community / rural region by developing community asset mapping or environmental scan, as well as community needs study in order to develop strategies and action plans to support sustainable communities. Asset mapping is another tool that has been used in North Carolina (Li et al., undated). It suggests inventory of seven types of community assets: Human (population growth, workforce skills, tourist presence); Social (community groups, religious organizations, social clubs); Physical (housing, internet access, community college system); Financial (community development lender, access to federal grants); Environmental (fertile soils, wetlands, public park access); Political (county economic initiatives, zoning ordinances); and Cultural (water main heritage, agricultural values, community festivals). Such asset mapping, coupled with other measures, may generate new ideas at the local level to stimulate economic growth.

\section{Acknowledgements}

This project was financially supported by the Saskatchewan Ministry of Agriculture, which is gratefully acknowledged. The manuscript benefited from comments made by two anonymous reviewers.

\section{REFERENCES}

[1] A. Ashkenazy, T. Chebach, K. Knickel, Sarah Petara, B. Horowotz, R. Offenbach. Operationalizing resilience in farms and rural regions - Findings from fourteen case 
studies. Journal of Rural Studies. Vol. 59. Pp. 211-221. 2018.

[2] R. Basile, B. Dowling, T. Salomon. Scorecard. Economic Development Journal. Vol. 10. No. 1. 50-57. 2011.

[3] R. D. Bollman, S. M. Ferguson. The local impacts of agricultural subsidies. Evidence from Canadian Prairies. Journal of Agricultural Economics. Vol. 70. No. 2. 507-528. 2019.

[4] D. Bruce, L. Ryser, G. Halseth, K. Giesbrecht. Economic development framework of small communities in Canada. Canada Mortgage and Housing Corporation Ottawa. 2005. Online available from: http://www.unbc.ca/assets/commun ity_development_institute/research/ecdevfw/phase_4_final _report.pdf.

[5] Council for Community and Economic Research. 2012 State economic development incentives survey report. 2013. Online available from: http://c23r.org/download/2012_Eco nomic_Development_Program_Survey_Report.pdf.

[6] S. Deller, T. Tsai, D. Marcouiller, D. English. The role of amenities and quality of life in rural economic growth. American Journal of Agricultural Economics. Vol. 83. No. 2. 352-365. 2001.

[7] Enterprise Saskatchewan. KPMG competitive alternatives: detailed analysis. Regina. 2012.

[8] Government of Saskatchewan. Economic review 2018. No. 72. Regina. 2019.

[9] Government of Saskatchewan. Enterprise Regions Program Launched in Regina. Online available from: https://www.s askatchewan.ca/government/news-and-media/2009/februar y/25/enterprise-regions-program-launched-in-regina. 2009.

[10] H. Hall, R. Olfert. State of rural Canada 2015: What is the future of rural Canada? 2015. Online available from: http://sorc.crrf.ca/saskatchewan/.

[11] International Economic Development Council. Economic development reference guide - incentives. Undated. Online available from: http://www.iedconline.org/index.php?p=G uide_Incentives.

[12] KPMG. 2016. Competitive Alternatives - KPMG's Guide to International Business Location Costs. KPMG Canada, Toronto.

[13] L. D. Kusmin. Factors associated with the growth of local and regional economies: A review of selected empirical literature. Staff Report AGES-9405. U. S. Department of Agriculture. Economic Research Service. Washington, D.C. 1994.

[14] J. L. LaSalle. Business Tax Credits and Incentives: A primer for good public-private partnerships. perspective on business and economic incentives. Jones Lang LaSalle's (JLL) Business and economic Incentives (BEI) practice. 2014. Online available from: http://www.us.jll.com/unitedstates/en-us/research/2043/business-tax-credits-incentives.

[15] Y. Li, W. Zheng, C. Stief. Asset mapping and sustainable development in Northeastern North Carolina. Undated. Durham: Duke University. Online available from: https://sites.duke.edu/nsoeclientgmp_resourcefulcommunit ies/.
[16] S. Mahroum, J. Atterton, N. Ward, A. M. Williams, R. Naylor, R. Hindle, F. Rowe. Rural innovation national endowment for science. Technology and the Arts. 2007. London. Online available at:https://media.nesta.org.uk/doc uments/rural_innovation.pdf.

[17] B. Moazzami. Strengthening rural Canada: fewer and older; population and demographic crossroads in rural Saskatchewan. 2015. A paper prepared for the Strengthening Rural Canada Initiative on behalf of Essential Skills Ontario and the Saskatchewan Literacy Network. Online available from: http//strengtheningruralca nada.ca/fileStrengthening-Rural-Canada-Fewer-and-OlderPopulation-and-Demographic-Crossroads-in-Rural-Saskatc hewan.pdf.

[18] M. E. Porter. Inner-city economic development: learnings from 20 years of research and practice. Economic Development Quarterly. Vol. 30. No. 2.105-116. 2016.

[19] M. Ofosuhene. A comparison of rural community development strategies in Saskatchewan and North Dakota. John G. McConnell (1935-1999). 73. 1999.

[20] D. V. Rainey, K. T. McNamara. (2002). Tax incentives: an effective development strategy for rural communities? Journal of Agricultural and Applied Economics. Vol. 34. No. 2. 319-325. 2002.

[21] W. Reid. (2013). A review of public incentives for economic development in Oregon. Portland: Oregon Economic Development Association. 2013.

[22] Saskatchewan Bureau of Statistics. Undated. Saskatchewan population report - 2016 census of Canada. Undated. Online available from: publications.gov.sk.ca.

[23] D. J. Savoie. Community economic development in Atlantic Canada: false hope or panacea. Moncton, NB: The Canadian Institute for Research on Regional Development. 2000.

[24] R. Shaffer, Ron, S. Deller, D. Marcouiller. Community Economics - Linking Theory and Practice. Ames, Iowa: Blackwell Publishing. 2004.

[25] SEDA -- Saskatchewan Economic Development Alliance. Saskatchewan Economic Development Concessions. Undated. Online available from: http://www.seda.sk.ca/im ages/file/Ec_Dev_concessions_Best520Practices.pdf.

[26] J. Stabler, R. Olfert. Saskatchewan’ communities in the 21st century - from places to regions. Regina: Canadian Plains Research Center, University of Regina. 2002.

[27] Statistics Canada. 2016 Census Profile. Rural municipality of Langenburg. 2016a. Online available from: https://www 12.statcan.gc.ca/census-recensement/2016/dp-pd/prof/detai ls/page.cfm?Lang=E\&Geo1=CSD\&Code1 $=4705047 \& G e o$ $2=$ CD\&Code $2=4705 \&$ Data $=$ Count $\&$ SearchText $=$ Langenb urg\&SearchType $=$ Begins $\&$ SearchPR $=01 \& B 1=$ All\&TABI $\mathrm{D}=1$. Ottawa.

[28] Statistics Canada. 2016 Census Profile. Rural municipality of Moose Jaw No. 161. 2016b. Online available from: https://www12.statcan.gc.ca/census-recensement/2016/dp$\mathrm{pd} /$ prof/details/page.cfm?Lang $=$ E\&Geo1 $=$ CSD\&Code1 $=4$ 707038\&Geo2 $=$ CD\&Code2 $=4707 \&$ Data $=$ Count $\&$ SearchT ext $=$ Moose $\% 20 J a w \&$ SearchType $=$ Begins $\&$ SearchPR $=01$ $\& B 1=$ All\&TABID $=1$. 
[29] Statistics Canada. 2016 Census Profile. Rural municipality of Mervin No. 499. 2016c. Online available from: https://www12.statcan.gc.ca/census-recensement/2016/dp$\mathrm{pd} /$ prof/details/page.cfm?Lang=E\&Geo1=CSD\&Code1=4 $717045 \& G e 02=\mathrm{CD} \&$ Code $2=4717 \&$ Data $=$ Count $\&$ SearchT ext=Mervin\&SearchType $=$ Begins $\&$ SearchPR $=01 \& B 1=$ All $\& \mathrm{TABID}=1$.

[30] Statistics Canada. 2016 Census Profile. Rural municipality of Orkney No. 244. 2016d. Online available from: https://www12.statcan.gc.ca/census-recensement/2016/dp$\mathrm{pd} /$ prof/details/pagepd/prof/details/page.cfm?Lang=E\&Ge o1 $=$ CSD \&Code $1=4709011 \&$ Geo $2=$ CD\&Code $2=4709 \& D a$ ta $=$ Count $\&$ SearchText=Orkney\&SearchType=Begins \&Sea $\operatorname{rchPR}=01 \& B 1=$ All $\&$ TABID $=1$.

[31] Statistics Canada. 2016 Census Profile. Rural municipality of Prairie Rose No. 309. 2016e. Online available from: https://www12.statcan.gc.ca/census-recensement/2016/dp$\mathrm{pd} /$ prof/details/page.cfm?Lang=E\&Geo1=CSD\&Code1 $=4$ $710052 \& G e 02=$ CD\&Code $2=4710 \&$ Data $=$ Count $\&$ SearchT ext=Prairie\%20Rose $\&$ SearchType $=$ Begins $\&$ SearchPR $=01$ $\& \mathrm{~B} 1=\mathrm{All} \& \mathrm{TABID}=1$.

[32] J. Straka, M. Tuzova. Factors affecting development of rural areas in the Czech Republic: A Literature review. Procedia - Social and Behavioral Sciences. Vol. 220. Pp. 496-505. 2016.

[33] Wikipedia. List of rural municipalities in Saskatchewan. 2018. Online available from: https://en.wikipedia.org/wiki/ List_of_rural_municipalities_in_Saskatchewan. 